\title{
WASIAT DAN HUTANG DALAM WARISAN
}

\author{
Nuzha \\ Sekolah Tinggi Agama Islam Negeri (STAIN) Majene \\ Totoli, Banggae, Kabupaten Majene, Sulawesi Barat \\ nuzhamuhammad@gmail.com
}

\begin{abstract}
:
When someone dead, there are two things related to heiress, the testament and debt. Pay the debt is obligated before the heiress divide by the join heirs. The testament consist of testament which given to someone except the join heirs, meanwhile the testament wajibah is given to child by adoption who does not receive the testament also to grand child whom parents dead quick or same with testament. Both of concepts has the law, requirements and problems which often face in social life with different condition.
\end{abstract}

Keywords: Testament, Debt, Heiress

\section{Pendahuluan}

\section{Latar Belakang Masalah}

Manusia dalam perjalanan hidupnya mengalami tiga peristiwa yang penting, yaitu ketika dilahirkan, ketika akan kawin, dan ketika dia meninggal dunia. Pada saat orang dilahirkan muncul tugas baru dalam kehidupan (keluarganya). Menurut arti sosiologis, ia menjadi pengembangan hak dan kewajiban. Kemudian, setelah dewasa ia akan melangsungkan perkawinan yang bertemu dengan lawan jenisnya untuk membangun dan menunaikan dharma bhaktinya yaitu kelangsungan keturunan. Selanjutnya, manusia pada akhirnya akan mengalami kematian meninggalkan dunia fana ini. Timbullah persoalan setelah orang meninggal dunia, apakah yang terjadi dengan segala sesuatunya yang ditinggalkan.

Hukum warismerupakansalahsatubagiandarihukum perdata secara keseluruhan dan merupakan bagian terkecil dari hukum kekeluargaan. Hukum waris sangat erat kaitannya dengan ruang lingkup hidup 
manusia, sebab setiap manusia pasti akan mengalami peristiwa hukum yang dinamakan kematian. Akibat hukum yang selanjutnya timbul dengan terjadinya peristiwa hukum kematian seseorang, diantaranya ialah bagaimana pengurusan hak-hak dan kewajiban-kewajiban si mayit misalnya saja wasiat dan hutang dari si mayit yang harus ditunaikan terlebih dahulu. ${ }^{1}$

\section{Wasiat}

\section{Pengertian}

Wasiat merupakan bahasa Arab yang disadur ke dalam bahasa Indonesia. Dalam kamus Bahasa Indonesia, wasiat diartikan dengan pesan terakhir yang disampaikan oleh orang yang akan meninggal dunia berkenaan dengan harta kekayaan dan sebagainya atau pusaka yang bertuah, gaib yang berarti ganjil, dapat mengadakan sesuatu yang aneh dan sebagainya. ${ }^{2}$

Menurut Bahasa Arab, wasiat yang terdiri huruf waw, shad, dan huruf $m u^{\prime}$ tal (ى) yang berarti menyambung sesuatu dengan sesuatu yang lain. Ibn Faris menambahkan bahwa washiyah terbentuk dari kata tersebut sehingga maknanya adalah perkataan yang disambung atau disampaikan dari orang yang meninggal kepada orang yang ditujukan pesan.

Makamuushiiorangyang berwasiatadalahorangyangmenyampaikan pesan di waktu dia hidup untuk dilaksanakan sesudah dia mati. Menurut istilah syara' wasiat adalah pemberian seseorang kepada orang lain baik berupa barang, pembebasan hutang, maupun manfaat untuk dimiliki orang yang diberi wasiat itu, sesudah orang yang berwasiat itu meninggal. Sebagian ahli hukum Islam memberikan definisi wasiat adalah pemberian hak milik secara sukarela, yang dilaksanakan setelah pemberinya meninggal dunia. ${ }^{3}$

Wasiat adalah amanah yang diberikan seseorang menjelang ajalnya atau dia membuat dan berwasiat dalam keadaan sedang tidak sehat,

\footnotetext{
${ }^{1}$ Eman Suparman, Hukum Waris Indonesia (Bandung: PT. Rineka Aditama, 2005), h. 1.

${ }^{2}$ Departemen Pendidikan RI, Kamus Bahasa Indonesia (Jakarta: Pusat Bahasa Departemen Pendidikan Nasional, 2008), h. 1618.

${ }^{3}$ Saebani, Hukum Perdata Islam di Indonesia (Bandung: CV. Pustaka Setia, 2011), h. 249.
}

Sangaji Jurnal Pemikiran Syariah dan Hukum 
artinya bukan ketika menjelang ajal. Wasiat dapat dipandang sebagai bentuk keinginan pemberi wasiat yang ditumpahkan kepada orang yang diberi wasiat. Oleh karena itu, tidak semua wasiat itu berbentuk harta. Ada kalanya wasiat itu berbentuk nasehat, petunjuk perihal tertentu, rahasia orang yang memberi wasiat dan sebagainya. ${ }^{4}$

Dari berbagai definisi tersebut dapat dijelaskan bahwa wasiat adalah pemberian seorang pewaris kepada orang lain selain ahli waris baik materi maupun non materi, yang berlaku setelah pewaris meninggal dunia.

\section{Dasar Hukum Wasiat}

QS. Al-Baqarah ayat 180-181:

Terjemahnya:

Diwajibkan atas kamu, apabila seorang di antara kamu kedatangan (tandatanda) maut, jika ia meninggalkan harta yang banyak, berwasiat untuk ibu-bapak dan karib kerabatnya secara ma'ruf, (ini adalah) kewajiban atas orang-orang yang bertakwa.

Maka barangsiapa yang mengubah wasiat itu setelah ia mendengarnya maka sesungguhnya dosanya adalah bagi orang-orang yang mengubahnya. Sesungguhnya Allah Maha Mendengar lagi Maha Mengetahui.

\section{Hadits}

Abu Umamah al-Bahily ra berkata: Aku mendengar Rasulullah SAW bersabda: "Sesungguhnya Allah telah memberi hak kepada tiap-tiap yang berhak dan tidak ada wasiat untuk ahli waris." (Riwayat Ahmad dan Imam Empat kecuali Nasa'i. Hadits hasan menurut Ahmad dan Tirmidzi, dan dikuatkan oleh Ibnu Khuzaimah dan Ibnu al-Jarud)

Dari ayat dan hadis tersebut, ada beberapa prinsip yang mengikat wasiat, yaitu:

1) Wasiat tidak diperkenankan kepada ahli waris berdasarkan hadits Nabi tersebut

Menurut al-Ma'la ali al-Qari bahwa sebelum turun ayat warisan, wasiat kepada kerabat dekat hukumnya wajib, namun sejak adanya

${ }^{4}$ Ibid., h. 343. 
warisan maka wasiat kepada keluarga dihapus (mansukh), karena kerabat dekat sudah ditentukan haknya melalui warisan. Dengan demikian, wasiat diperuntukkan kepada kerabat yang tidak termasuk dalam ahli waris dan juga kepada orang lain.

Para ulama tafsir seperti al-Qurthubi, al-Syaukani, Shadiq Hasan Khan juga sepakat dengan al-Qari bahwa adanya wasiat kepada ahli waris yang dinilai sebagai sesuatu yang mansukh dan sebagian lagi menyatakan bahwa ayat tersebut muhkam. Pendapat tersebut hanya mengurai kembali pendapat ulama, tanpa menyatakan sikap dan keberpihakan mereka kepada salah satu pendapat yang ada. Dalam hal ini, Tahntawiy Jauhari memandang bahwa pada masa awal Islam, wasiat kepada ahli waris adalah sesuatu yang dibolehkan, namun pada masa sesudahnya perbuatan tersebut di-nasakh oleh ayat mawaris.

Namun, menurut al-Thabariy maksud dari perintah QS. alBaqarah/2:180 tersebut adalah wasiat yang ditujukan kepada ahli waris, yang dalam keadaan tertentu terhalang untuk menerima bagian-bagian mereka, sesuai dengan bagian yang telah ditentukan.

Terlepas dari berbagai pandangan ulama, hukum Islam secara umum berlandaskan keadilan kepada semua pihak yang terlibat dalam kewarisan sehingga setiap orang yang hadir pada saat pembagian harta yang terdapat di dalam al-Qur'an, dianjurkan untuk diberikan masing-masing bagian. Sangat tidak adil, jika seandainya pembagian warisan masih ada orang-orang yang terlantar dan tidak mendapat bagian apapun, apalagi pihak tersebut berasal dari kedua orang tua atau kerabat terdekat.

Wasiat kepada ahli waris pada masa awal Islam mengisyaratkan distribusi keadilan dalam pembagian kepada setiap orang dalam ahli waris. Selanjutnya, syariat menyatakan hal tersebut sebagai perbuatan yang terhapus dengan anggapan bahwa perbuatan tersebut sudah tidak lagi mencerminkan distribusi keadilan, seperti yang diharapkan dalam proses tersebut. Jika, tetap dipertahankan maka ahli waris yang tidak terhalang akan berlipat ganda bagiannya. Hal tersebut, mengusik rasa keadilan, sehingga perlu untuk menganulir aturan terdahulu dengan ayat-ayat kewarisan. 
Salah satu aspek yang berkaitan langsung dengan hukum adalah keadilan, bahkan sangat sulit jika ada upaya untuk memisahkan hukum dari keadilan. Tendensi untuk mengidentikkan hukum dengan keadilan adalah tendensi yang menjustifikasi suatu tata aturan sosial.

Salah satu tendensi dari peniadaan wasiat kepada para ahli waris dalam hukum Islam adalah terdistribusinya rasa keadilan kepada ahli waris. Kondisi tertentu juga dapat menyebabkan terhalangnya ahli waris untuk mendapatkan harta warisan dari pewaris, untuk kasus serupa maka solusi yang ditawarkan guna menimbulkan suasana terdistribusinya keadilan kepada semua pihak adalah wasiat kepada ahli waris.

Walaupun dinyatakan sebagai produk hukum yang terhapus (mansukh), namun tidak serta merta hal tersebut menghilangkan seluruh aspek hukum yang diatur dalam wasiat kepada ahli waris dapat saja terhalangi karena perbedaan agama antara pewaris dengan ahli waris atau karena yang lain.

Wasiat kepada ahli waris, oleh para ulama dianggap sebagai sebuah solusi untuk mencari jalan keluar dari kebuntuan distribusi keadilan kepada ahli waris lainnya. Dikatakan demikian, karena wasiat kepada ahli waris memungkinkan untuk mendistribusikan bagian tertentu kepada ahli waris yang terhalang dan di satu sisi dinyatakan mansukh karena terjadi pembagian berganda kepada pihak ahli waris di kalangan orang tua dan kerabat dekat.

Secara diskursus tentang wasiat kepada ahli waris akan bermuara pada dua aspek yang berkaitan langsung dengan rasa keadilan dalam masyarakat. Untuk hal inilah hukum Islam mengkristal menjadi hukum yang hidup di tengah-tengah masyarakat yang menganutnya. Setidaknya dua keadaan nyata yang timbul dari wasiat kepada ahli waris, yaitu:

a) Terjadinya peluang distribusi harta warisan kepada ahli waris yang terhalang oleh kondisi tertentu dalam konteks syarat.

b) Tidak terjadinya bagian-bagian ganda terhadap ahli waris yang telah mendapatkan bagian warisan.

Setidaknyakonklusi tersebutmewakiliduagolongandiantaranya 
menurut al-Thabary maksud dari perintah untuk berwasiat dalam QS al-Baqarah/2:180 adalah wasiat yang ditujukan kepada ahli waris yang dalam keadaan tertentu terhalang untuk menerima bagianbagian mereka, sesuai dengan kadar-kadar yang telah ditentukan dengan jalan ma'ruf. Sedangkan menurut al-Qurthubiy, al-Syaukani, Shadiq Hasan Khan, mengemukakan persepsi ulama mengenai adanya wasiat kepada ahli waris yang dinilai sebagai sesuatu yang mansukh dan sebagian lagi menyatakan bahwa ayat tersebut muhkam. Kewarisan perwasiatan senantiasa berupaya untuk menumbuhkan semangat sosial secara kolektif.

2) Wasiat tidak diperkenankan lebih dari $1 / 3$ harta orang yang berwasiat. Hal tersebut, dapat dipahami dari kasus Abu Waqqash yang dilarang Rasulullah SAW, berwasiat untuk bersedekah lebih dari $1 / 3$ hartanya, meskipun ahli warisnya hanya seorang perempuan saja.

3) Wasiat ditetapkan hukum kepemilikannya setelah pewasiat meninggal, sehingga serah terima yang dilakukan sebelum kematian dianggap tidak berkekuatan hukum.

4) Wasiat menetapkan status orang yang diberi wasiat sama, baik yang disebutkan pertama maupun yang disebutkan terakhir, karena wasiat merupakan pemberian setelah kematian pewasiat.

5) Orang yang memberikan tidak dapat membatalkan pemberian tersebut setelah barangnya diterima oleh orang yang diberi, berbeda dengan wasiat, yang mana pemberi wasiat dapat membatalkan wasiatnya. ${ }^{5}$

\section{Hukum Wasiat}

Helmi Karim mengatakan hukum melakukan wasiat bervariasi, ada yang wajib, sunnah, makruh bahkan ada yang haram, sesuai dengan situasi dan kondisi, yaitu:

${ }^{5}$ Abdul Gaffar, Hibah dalam Perspektif Hadis Nabi (Cet. 1; Makassar: Alauddin University Press, 2013), h. 64-69. 
a. Wasiat yang hukumnya wajib, yakni seseorang yang diwajibkan melakukan wasiat sebelum ia meninggal dunia. Wasiat ini bertujuan, untuk membayar hutang dan menunaikan kewajiban. Contohnya, wajib berwasiat untuk mengembalikan pinjaman atau untuk membayar hutang.

b. Wasiat yang hukumnya dianjurkan (mustahabbah) supaya dilakukan oleh seseorang sebelum ia meninggal dunia. Contohnya, berwasiat untuk karib kerabat yang bukan termasuk ahli waris, sehingga mereka ikut terbantu.

Mewasiatkan sesuatu kepada orang yang bukan ahli waris adalah sangat disukai (mustahab). Demikian ijma para imam mazhab. Az-Zuhri dan ulama ahlu Zahir mengatakan bahwa berwasiat untuk kerabat yang tidak mendapat warisan dari si mayit hukumnya adalah wajib, baik mereka itu dari ashabah maupun dari dzawil arham, yaitu jika terdapat ahli waris lain selain mereka.

c. Wasiat yang sifat dan hukumnya boleh dilakukan oleh seseorang sebelum ia meninggal dunia, seperti berwasiat untuk orang-orang kaya, baik termasuk keluarga yang tidak menerima orang.

d. Wasiat yang sifatnya karahah tahrim, sebagaimana dikemukakan mazhab Hanafi. Contoh berwasiat untuk ahli fasik dan ahli maksiat.

e. Wasiat yang hukumnya haram, yakni wasiat yang tidak boleh dilakukan oleh seorang muslim, seperti berwasiat untuk maksiat. Contoh berwasiat supaya uangnya dipergunakan untuk mencetak buku-buku yang menyesatkan dan lain-lain. ${ }^{6}$

\section{Rukun dan Syarat Wasiat}

a. Rukun wasiat

1. Orang yang berwasiat

2. Orang yang menerima wasiat

3. Barang yang diwasiatkan, berupa harta atau manfaat sesuatu

4. Ijab kabul, secara lisan maupun tulisan. ${ }^{7}$

${ }^{6}$ Helmi Karim, Figh Muamalah (Cet. III; Jakarta: PT. Raja Grafindo Persada, 2002), h. 90-91.

${ }^{7}$ Chairuman Pasaribu, Hukum Perjanjian dalam Islam (Jakarta: Sinar Grafika, 1994), 122. 
b. Syarat wasiat

1. Orang yang memberi wasiat telah baligh, berakal, benar-benar pemilik atas harta benda yang diwasiatkan. Disamping itu pewasiat tidak dalam pengaruh atau tekanan.

2. Orang yang menerima wasiat masih hidup.

3. Jika yang diwasiatkan harta, jumlahnya tidak melebihi sepertiga.

4. Wasiat diberikan jika pemberi wasiat telah meninggal.

5. Pernyataan yang jelas. ${ }^{8}$

Wasiat tidak menjadi hak orang yang diberinya, kecuali setelah pemberinya meninggal dunia dan hutang-hutangnya diselesaikan. Apabila hutang-hutangnya menghabisi semua peninggalan, maka orang yang diberi tidak mendapat apa-apa. ${ }^{9}$

\section{Batalnya Wasiat}

Menurut Abu Yusuf, apabila orang yang diberi wasiat membunuh orang yang memberinya wasiat dengan pembunuhan yang diharamkan secara langsung, maka wasiat itu batal. Sebab, orang yang menyegerakan sesuatu sebelum waktunya, dihukum dengan tidak mendapatkan sesuatu itu. Abu Hanifah dan Muhammad berpendapat bahwa wasiat itu tidak batal dan ini diserahkan kepada persetujuan ahli waris. ${ }^{10}$

Menurut Sayyid Sabiq wasiat itu batal dengan hilangnya salah satu syarat dari syarat yang ada pada wasiat, misalnya sebagai berikut :

a. Bila orang yang berwasiat itu menderita penyakit gila yang parah yang menyampaikannya pada kematian.

b. Bila orang yang diberi wasiat mati sebelum orang yang memberi wasiat itu mati.

c. Bila yang diwasiatkan itu barang tertentu yang rusak sebelum diterima oleh orang yang diberi wasiat. ${ }^{11}$

${ }^{8}$ Sudarsono, Sepuluh Aspek Agama Islam (Jakarta: PT. Rineka Cipta, 1994), h. 345.

${ }^{9}$ Ibid., h. 253.

${ }^{10}$ M. Ali Hasan, Hukum Waris dalam Islam (Cet. VI; Jakarta: PT. Bulan Bintang, 1996), h. 253.

${ }^{11}$ Elimartati, Hukum Perdata Islam di Indonesia (Batusangkar: STAIN Batusangkar Press, 2010), h. 69-70.

Sangaji Jurnal Pemikiran Syariah dan Hukum 


\section{Permasalahan Dalam Wasiat}

Contoh permasalahan dalam wasiat:

a. Para imam mazhab sepakat bahwa berwasiat untuk selain ahli waris sebanyak sepertiga bagian adalah dibolehkan dan tidak memerlukan persetujuan ahli waris. Sedangkan berwasiat untuk ahli waris dibolehkan setelah mendapat persetujuan dari ahli waris yang lain. ${ }^{12}$

Menurut pendapat mazhab Maliki, apabila telah diwasiatkan lebih dari sepertiga bagian dari harta pusaka, dan ahli waris pun menyetujuinya, maka jika persetujuan dibuat dalam keadaan sakit, tidak boleh dicabut persetujuannya, sesudah orang yang mati itu memberikan wasiat. Jika, persetujuan tersebut dibuat ketika pemberi wasiat dalam keadaan sehat, maka ahli waris boleh mencabut kembali persetujuannya, sesudah pemberi wasiat meninggal dunia. Sedangkan, Hanafi dan Syafi'i mengatakan bahwa mereka berhak menarik kembali persetujuannya, baik persetujuan tersebut dibuat ketika pemberi wasiat dalam keadaan sakit maupun dalam keadaan sehat. ${ }^{13}$

b. Apabila orang yang sedang sakit tidak dapat berbicara, apakah sah wasiatnya dengan menggunakan isyarat? Menurut pendapat Hanafi dan Hambali tidak sah. Menurut pendapat Syafi'i sah sedangkan menurut pendapat Maliki dibolehkan.

c. Apabila orang yang menerima wasiat untuk mengurus harta telah menerima wasiat ketika pemberi wasiat masih hidup maka ia tidak boleh menolak sesudah pemberi wasiat itu meninggal. Demikian menurut Hanafi dan Maliki. Hanafi berpendapat ia tidak boleh menolak semasa hidupnya pemberi wasiat, kecuali pemberi wasiat itu datang menyaksikannya. Syafi'i dan Hambali mengatakan ia boleh menolak kapan saja dan membebaskan diri dari urusan itu.

An-Nawawi berpendapat tidak boleh ia menolak jika ternyata dialah yang seharusnya menjalankan tugas menyelesaikan wasiat atau menurut dugaannya, jika ia tidak menyelesaikannya, mungkin

${ }^{12}$ Syaikh al-Allamah Muhammad bin Abdurrahman ad-Dimasyqi, Figh Empat Mazhab (Cet. II; Bandung: Hasyimi, 2004), h. 330.

${ }^{13}$ Abdul Shomad, Hukum Islam Penormaan Prinsip Syariah dalam Hukum Indonesia (Jakarta: Kencana Prenada Media Group, 2010), h. 356. 
harta tersebut akan musnah lantaran perbuatan orang zalim. ${ }^{14}$

d. Apabila seseorang mewasiatkan suatu barang kepada seseorang, lalu pemberi wasiat itu mewasiatkannya lagi kepada orang lain, tetapi ia tidak tegas menerangkan bahwa ia telah mencabut wasiatnya yang pertama, maka barang tersebut harus dibagi dua. Demikian menurut kesepakatan para imam mazhab.

e. Apakah orang yang mendapat wasiat dapat memiliki sesuatu yang diwasiatkan setelah pemberi wasiat meninggal atau setelah dilakukan serah terima atau kah ditangguhkan? Syafi'i mempunyai tiga pendapat dalam masalah ini, tetapi pendapat yang paling kuat adalah ditangguhkan, yakni tidak terus menjadi milik penerima wasiat. Sedangkan menurut pendapat Hanafi, Maliki dan Hambali, dimiliki setelah dilakukan serah terima.

f. Menurut pendapat Hanafi, Maliki dan Hambali, barangsiapa berwasiat kepada seseorang agar diberikan unta untuk orang tertentu, maka boleh diberikan kepadanya unta betina. Juga, jika ia berwasiat agar diberikan unta betina yang gemuk atau sapi, maka boleh diberikan yang jantan, keduanya sama saja. Sedangkan Syafi'i berpendapat tidak boleh dalam membayarkan wasiat unta kecuali yang jantan dan dalam unta betina dan sapi, kecuali yang betina. ${ }^{15}$

Al-Hasan Atha dan Thawus mengatakan bahwa berwasiat kepada orang kedua berarti membatalkan wasiat yang pertama. Dengan demikian, wasiat tersebut untuk orang kedua. Sedangkan Dawud berpendapat tetap menjadi milik yang pertama. ${ }^{16}$

g. Apabila seseorang berwasiat agar dikeluarkan sepertiga hartanya untuk memerdekakan budak, maka harus dimulai dengan memerdekakan budak-budaknya, sebagaimana zakat. Demikian menurut pendapat Maliki, Hanafi dan Syafi'i mengatakan hendaknya diberikan kepada budak yang telah dijanjikan tuannya untuk dimerdekakan.

Memerdekakan budak, memberi hibah, wakaf dan semua

${ }^{14}$ Syaikh al-Allamah Muhammad bin Abdurrahman ad-Dimasyqi, Figh Empat Mazhab (Cet. II; Bandung: Hasyimi, 2004), h. 336.

${ }^{15}$ Ibid., h. 331.

${ }^{16}$ M. Ali Hasan, Hukum Waris Dalam Islam, (Cet. VI; Jakarta: PT. Bulan Bintang, 1996), h. 25. 
pemberian yang dilakukan dalam keadaan sakit yang membawa kematian dihitung dari sepertiga harta. Hal ini menjadi kesepakatan para ulama. Mujtahid dan Dawud mengatakan dihitung dari pokok harta.

h. Para imam mazhab berbeda pendapat tentang berwasiat kepada budak. Maliki dan Hambali mengatakan bahwa sah secara mutlak, baik diberikan kepada budak maupun lainnya, sama saja. Syafi'i berpendapat tidak sah secara mutlak. Hanafi berpendapat sah jika diberikan kepada budaknya sendiri, dengan syarat tidak ada diantara orang yang mendapat warisan orang yang sangat tua dan tidak sah berwasiat untuk budak orang lain.

i. Para imam mazhab berbeda pendapat tentang berwasiat untuk orang kafir. Dalam hal ini, Maliki, Syafi'i dan Hambali mengatakan bahwa wasiat tersebut adalah sah, baik diberikan kepada ahli harb maupun kafir dzimmi. Hanafi berpendapat tidak sah wasiat untuk ahli harb tetapi sah untuk kafir dzimmi.

j. Apabila orang yang diserahi urusan wasiatitu seorang yang adil maka tidak diperlukan penetapan hakim. Pelaksanaan wasiat diserahkan kepadanya diri sendiri dan segala pembelanjaannya dianggap sah. Demikian menurut Maliki, Syafi'i dan Hambali. Sedangkan Hanafi berpendapat jika tidak dibenarkan oleh hakim maka seluruh barang yang dibeli dan dijual untuk kepentingan orang yang diwasiati jadi tertolak. Tetapi pembelanjaan yang dikeluarkannya dianggap sah.

k. Menurut Hanafi, Syafi'i dan Hambali, barang yang diwasiatkan harus dijelaskan dan ditentukan. Jika wasiat itu bersifat mutlak, seperti orang yang berkata: "Aku berwasiat kepadamu", maka wasiat tersebut tidak sah, karena yang demikian itu seperti mainmain. Maliki berpendapat, wasiatnya adalah sah dan orang yang menerima urusan wasiat berhak mengurus segalanya. Dari Maliki diperoleh riwayat yang lain, yaitu bahwa wasiatnya tidak sah, kecuali jika dijelaskan benda yang diwasiatkan tersebut.

1. Apabila seseorang berwasiat untuk kerabat-kerabatnya maka tidak termasuk ke dalamnya anak-anak dari anak perempuan. Sebab, anak-anak dari anak perempuan tidak termasuk cucu yang mendapat warisan. Oleh karena itu, hendaknya diberikan kepada kerabat, lalu 
yang lebih dekat lagi. Demikian menurut pendapat Maliki. Hanafi berpendapat yang dimaksud kerabat-kerabatnya adalah orangorang yang mempunyai hubungan nasab dengannya, tetapi tidak diberikan kepada anak-anak paman dan anak-anak saudara ibu. ${ }^{17}$

Syafi'i berpendapat apabila seseorang mengatakan "Aku berwasiat untuk kerabat-kerabatku", maka termasuk kedalamnya adalah semua kerabat, meskipun yang jauh, kecuali pokok (ayah dan kakek) dan furu' (anak dan cucu laki-laki dari anak laki-laki). Apabila orang yang berwasiat itu mengatakan "Untuk keturunanku dan cucu-cucuku", maka termasuk kedalamnya anak perempuan. Hambali mengatakan dalam salah satu riwayatnya: orang yang menjadi kerabat dalam hidupnya boleh diberikan wasiat. Jika tidak ada, maka wasiatnya dberikan kepada kerabat-kerabatnya dari pihak ayah.

m. Berwasiat untuk orang yang telah mati hukumnya batal. Demikian menurut pendapat Hanafi, Syafi'i dan Hambali. Sedangkan Maliki berpendapat sah wasiatnya. Dengan demikian, jika orang yang sudah meninggal itu mempunyai hutang atau kafarah maka dibayarlah dengan barang wasiat tersebut. Sedangkan jika ia tidak mempunyai hutang atau tanggungan kafarah maka diberikan kepada ahli warisnya.

n. Apabila seseorang berwasiat untuk orang lain sebanyak 1.000, sedangkan harta yang ada padanya hanya 1.000 dan harta lainnya yang tidak ada tempatnya, berupa kebun atau berupa piutang yang masih ada pada orang lain dan ahli warisnya pun kikir. Mereka mengatakan "Kami tidak menyerahkan kepada orang yang diserahi urusan wasiat kecuali sepertiga dari 1.000 itu". Maka semua hartanya itu tidak untuk mereka. Demikian menurut pendapat Maliki. Sedangkan menurut Hanafi, Syafi'i dan Hambali mengatakan bahwa orang yang diwasiati mendapat sepertiga dari 1.000. Sisanya merupakan hak yang ada dalam perserikatan dalam semua harta yang ditinggalkan pemberi wasiat yang harus dipenuhi haknya.

${ }^{17}$ Syaikh al-Allamah Muhammad bin Abdurrahman ad-Dimasyqi, Figh Empat Mazhab (Cet. II; Bandung: Hasyimi, 2004), h. 333.

Sangaji Jurnal Pemikiran Syariah dan Hukum 
o. Apabila seseorang berwasiat untuk seseorang yang merdeka yang berayah seorang budak. Lalu, wasiat itu diterima, sedangkan si anak (penerima wasiat) dalam keadaan sakit. Setelah itu, ayah si anak menjadi merdeka dan si anak itu meninggal dunia. Dalam hal ini, si ayah tidak menerima waris dari anaknya. Demikian menurut pendapat Syafi'i dan Hambali. Sedangkan menurut pendapat Maliki dan jumhur ulama si ayah tersebut berhak menerima waris dari anaknya.

p. Apabila seseorang menuliskan wasiatnya sendiri dan diketahui bahwa tulisan tersebut adalah tulisannya, tetapi tidak ada saksi yang menyaksikannya, maka apakah wasiat itu dapat ditetapkan dengan tulisan tersebut sebagaimana jika disaksikan oleh dirinya sendiri? Menurut pendapat Hanafi, Maliki dan Syafi'i mengatakan tidak dapat ditetapkan dengan tulisan tersebut. Sedangkan Hambali berpendapat dapat ditetapkan dengan tulisan tersebut selama tidak diketahui bahwa ia telah menarik wasiatnya.

q. Orang yang mempunyai ayah dan kakek tidak boleh berwasiat kepada orang lain untuk mengurusi keperluan anak-anaknya, sesudah ia meninggal, kecuali jika penerima wasiat itu orang yang adil. Demikian menurut pendapat Syafi'i dan Hambali. Hanafi dan Maliki berpendapat sah berwasiat kepada orang lain untuk mengurus keperluan anak-anaknya dan membayar hutang-hutangnya serta mengurus sepertiga hartanya, meskipun ada ayah atau kakek.

v. Orang yang diserahi urusan wasiat boleh menyerahkan kepada orang lain, walaupun tidak mendapat pembenaran yang jelas dari orang yang mewasiatkan, menurut pendapat Hanafi dan para ulama pengikutnya, serta menurut pendapat Maliki. Menurut Syafi'i dan pendapat Hambali dalam salah satu riwayatnya tidak dibolehkan.

r. Apabila anak yang belum baligh berwasiat dan ia sudah mengerti maksud wasiatnya, maka wasiatnya dianggap sah. Demikian menurut Maliki. Hanafi berpendapat, tidak dibolehkan. Pendapat Syafi'i saling berbeda, tetapi berpendapat yang paling shahih dalam mazhabnya adalah tidak sah. Demikian juga pendapat mazhab Hambali menyatakan tidak sah.

s. Apabila orang tersebut mewasiatkan seluruh hartanya, sedangkan 
ia tidak mempunyai ahli waris, maka wasiatnya dianggap sah. Demikian menurut pendapat Hanafi dan Hambali dalam salah satu riwayatnya. Menurut pendapat Syafi'i, satu riwayat Maliki dan riwayat lain dari Hambali wasiatnya tidak sah kecuali sepertiga saja.

t. Apabila seseorang berwasiat kepada dua orang untuk menyelesaikan suatu perkara tanpa menyebutkan suatu urusan yang harus diselesaikan oleh keduanya, apakah boleh salah satunya menyelesaikannya sendiri tanpa yang lain? Menurut Maliki, Syafi'i dan Hambali, tidak boleh secara mutlak. Sedangkan Hanafi berpendapat boleh diselesaikan oleh seorang saja dalam delapan perkara, yaitu:

1. Membelikan kain kafan

2. Mengurus biaya penguburan mayat

3. Memberi makan kepada anak-anak kecil

4. Memberikan pakaian kepada mereka

5. Mengembalikan jaminan yang berupa benda

6. Membayar hutang

7. Menyelesaikan wasiat tertentu

8. Memerdekakan budak tertentu dan memperkarakan hak orang mati $^{18}$

u. Apabila seseorang mempunyai tiga anak laki-laki. Lalu ia berwasiat untuk orang lain sebanyak bagian salah seorang diantara mereka. Maka ia berhak menerima seperempat bagian. Demikian menurut pendapat Hanafi, Syafi'i dan Hambali. Maliki berpendapat ia berhak menerima sepertiga bagian saja. ${ }^{19}$

\section{Wasiat Wajibah}

Wasiatwajibah merupakan kebijakan penguasa yang bersifat memaksa untuk memberikan wasiat kepada orang tertentu, pada waktu tertentu. ${ }^{20}$ Wasiat wajibah adalah suatu wasiat yang diperuntukkan kepada ahli waris kepada ahli waris atau kerabat yang tidak memperoleh bagian

${ }^{18}$ Syaikh al-Allamah Muhammad bin Abdurrahman ad-Dimasyqi, Figh Empat Mazhab (Cet. II; Bandung: Hasyimi, 2004), h. 335.

${ }^{19}$ Ibid., h. 334.

${ }^{20}$ Fathur Rahman, Ilmu Waris (Jakarta: PT. Bulan Bintang, 1979), h. 63. 
harta warisan, karena adanya halangan syara'. ${ }^{21}$ Menurut Suparman wasiat wajibahadalah wasiat yang pelaksanaannya tidak dipengaruhi oleh kemauan si mayit. ${ }^{22}$

Orang-orang yang mendapat wasiat wajibah adalah cucu-cucu, yang orang tuanya telah mati mendahului atau berbarengan dengan pewaris. Mereka diberi wasiat wajibahsebesar bagian orang tuanya dengan ketentuan tidak melebihi dari 1/3 peninggalan. Oleh karena besar kecilnya bagian orang tuanya itu tergantung dengan sedikit atau banyaknya saudara orang tuanya, maka ada kemungkinan bahwa bagian orang tuanya $1 / 5,1 / 4,1 / 3$ atau $1 / 2$ peninggalan, kelebihannya itu harus dikembalikan kepada ahli waris. Walaupun, cucu tersebut dapat menduduki kedudukan orang tuanya dalam memperoleh harta warisan, namun jumlah yang diterimanya itu bukan semata-mata berdasarkan mempusakai, tetapi berdasarkan wasiat wajibah. Oleh karena itu, memberikan bagiannya harus didahulukan dari pada memberikan bagian kepada ahli waris. ${ }^{23}$

Dasar hukum penentuan wasiat wajibah adalah kompromi dari pendapat-pendapat ulama salaf dan khalaf yang menurut Fathur Rahman adalah tergantung kewajiban berwasiat kepada kerabat, kerabat yang tidak dapat menerima pusaka ialah diambil dari pendapat-pendapat fuqaha' dan tabi'in besar ahli fiqih dan ahli hadits antara lain Sain bin Musayyad, Hasan Al-Basyri, Thawus, Ahmad Ishak bin Rahawib dan Ibnu Hazm.

Pemberian sebagian harta si mayit kepada kerabat-kerabat yang tidak dapat menerima pusaka yang berfungsi wasiat wajibah, bila si mayit tidak berwasiat adalah diambil dari pendapat mazhab Ibnu Hazm yang dinukilkan dari fuqaha', tabi' in dan pendapat Ahmad.

Pengkhususan kerabat-kerabat yang tidak menerima pusaka kepada cucu dan pembatasan penerimaan sebesar $1 / 3$ peninggalan

${ }^{21}$ Abdul Aziz Dahlan, Ensiklopedi Hukum Islam (Jakarta: PT. Ikhtiar Baru Van Houve, 2000), h. 1930.

${ }^{22}$ Suparman, Fiqh Mawaris (Hukum Kewarisan Islam) (Jakarta: Gaya Media Pratama, 1997), h. 163.

${ }^{23}$ Abdul Shomad, Hukum Islam Penormaan Prinsip Syariah dalam Hukum Indonesia (Jakarta: Kencana Prenada Media Group, 2010), h. 365. 
adalah didasarkan kepada Ibnu Hazm, dan kaedah yang berbunyi "pemegang kekuasaan mempunyai wewenang perkara mubah karena ia berpendapat bahwa hal itu membawa kemaslahatan umum. Bila penguasa memerintahkan demikian wajiblah ditaati".

\section{Perbedaan Wasiat dengan Wasiat Wajibah}

\begin{tabular}{|c|l|l|l|}
\hline No & \multicolumn{1}{|c|}{ Perbedaan } & \multicolumn{1}{c|}{ Wasiat Biasa } & \multicolumn{1}{c|}{ Wasiat Wajibah } \\
\hline 1 & $\begin{array}{l}\text { Dari segi yang } \\
\text { orang menerima } \\
\text { wasiat. }\end{array}$ & $\begin{array}{l}\text { Orang lain selain } \\
\text { orang yang menjadi } \\
\text { ahli waris. }\end{array}$ & $\begin{array}{l}\text { - Diberikan kepada anak } \\
\text { angkat yang tidak mendapat } \\
\text { wasiat biasa. }\end{array}$ \\
& & $\begin{array}{l}\text { Cucu laki-laki maupun cucu } \\
\text { perempuan yang orang } \\
\text { tuanya mati mendahului } \\
\text { atau bersama-sama kakek } \\
\text { atau neneknya (pewasiat). }\end{array}$ \\
\hline 2 & Dari segi hukum & $\bullet$ Sunnah & - Wajib \\
\hline
\end{tabular}

\section{A. HUTANG DALAM WARISAN}

Kata hutang dalam kamus bahasa Indonesia terdiri atas dua suku kata yaitu hutang yang mempunyai arti uang yang dipinjamkan dari orang lain. Sedangkan kata piutang mempunyai arti uang yang dipinjamkan (dapat ditagih dari orang lain).

Pengertian hutang piutang adalah memberikan sesuatu yang menjadi hak milik pemberi pinjaman kepada peminjam dengan pengembalian di kemudian hari sesuai perjanjian dengan jumlah yang sama. Jika peminjam diberi pinjaman Rp. 1.000.000 maka di masa depan si peminjam akan mengembalikan uang sejumlah satu juta juga.

Hukum hutang piutang bersifat fleksibel tergantung situasi kondisi dan toleransi. Pada umumnya pinjam-meminjam hukumnya sunah bila dalam keadaan normal. Hukumnya haram jika meminjamkan uang untuk membeli narkoba, berbuat kejahatan, menyewa pelacur, dan lain sebagainya. Hukumnya wajib jika memberikan kepada orang yang sangat membutuhkan seperti tetangga yang anaknya sedang sakit keras dan membutuhkan uang untuk menebus resep obat yang diberikan oleh dokter. ${ }^{24}$ h. 2 .

${ }^{24}$ Abu Humaid Arif Syarifuddin, Al-Manhaj (Surakarta: Yayasan Lajnah Istiqamah, 2005), 
Adapun yang menjadi dasar hutang piutang dapat dilihat pada ketentuan QS. al-Maidah/5: 2

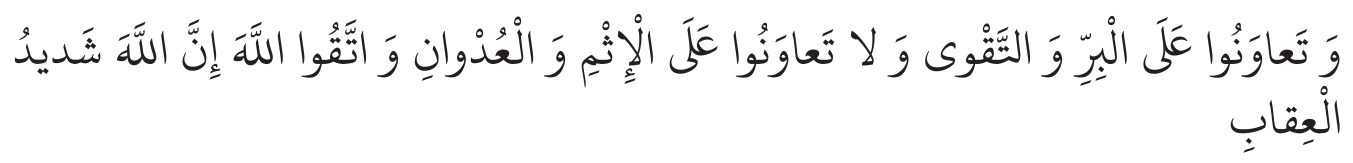

Terjemahnya:

...Dan tolong-menolonglah kamu dalam (mengerjakan) kebajikan dan takwa, dan jangan tolong-menolong dalam berbuat dosa dan pelanggaran

Sedangkan dalam sunnah Rasulullah SAW ditemukan antara lain dalam sebuah hadis yang diriwayatkan oleh Ibnu Majah "Seorang muslim yang mempiutangi seorang muslim dua kali, seolah-olah telah bersedekah kepadanya satu kali".

Di dalam kehidupan sehari-harinya seseorang tidak terlepas daribeban dan tanggungan. Di antara tanggungan yang mungkin menimpanya ialah hutang. Terutama ketika kondisi yang mendesak dan amat membutuhkan, atau kondisi-kondisi lainnya. Baik hutang tersebut terkait dengan hak manusia atau pun yang terkait dengan hak Allah. Islam sebagai agama yang sempurna telah mengatur masalah ini, sebagaimana telah tertuang dalam Kitabullah maupun Sunnah Rasulullah SAW. Adapun yang terkait hak manusia, Rasulullah SAW sendiri pernah berhutang. Seperti pernah diceritakan oleh Aisyah: "Bahwa Nabi SAW pernah membeli makanan dari seorang Yahudi dengan harga pembayaran di belakang (hutang) dan memberi jaminan dengan baju besi milik beliau".

Hadits tersebut menunjukkan adanya dalil bolehnya ber-muamalah dengan ahli dzimmah (kafir dzimmi), dan boleh memberi suatu jaminan untuk hutang di saat mukim.

Meski Nabi SAW berhutang, beliau adalah orang yang senantiasa ingin bersegera dalam membayar hutangnya dan melebihkan pembayarannya. Jabir ra mengisahkan. "Aku mendatangi Nabi SAW ketika beliau di Masjid Mis'ar berkata: Saya kira ia menyebut waktu Dhuha. Lalu Nabi SAW memiliki hutang kepadaku. Maka beliau melunasinya dan memberiku tambahan."

Demikianlah seharusnya setiap muslim mencontoh Rasulullah SAW. Sehingga, hutang yang menjadi tanggungan diri seorang muslim, 
hendaknya segera ditunaikan bila telah memiliki harta yang dapat untuk melunasinya, tidak mengulur-ulurnya, karena hal itu termasuk bentuk kezhaliman. Hutang ini tetap akan menjadi tanggungannya, sampai ia mati sekalipun. Jika belum dilunasi, maka ruhnya akan tergantung sampai terlunasi hutangnya tersebut. Nabi SAW bersabda (Penguluran (hutang) oleh orang yang mampu (membayar) adalah kezhaliman). Beliau juga bersabda (Jiwa (ruh) seorang mukmin tergantung karena hutangnya, sampai terlunasi)..$^{25}$

Nabi SAW pernah tidak mau mensholatkan jenazah seseorang, karena si mayit tersebut masih memiliki tanggungan hutang. Salamah bin Al-Akwa r.a. menuturkan

Bahwasanya, pernah dihadapkan kepada Nabi SAW seorang jenazah untuk beliau shalati. Lalu beliau bertanya, "Apakah dia punya hutang?" Mereka menjawab, "Tidak", maka beliau pun menyalatinya. Kemudian didatangkan kepada beliau jenazah yang lain, lalu beliau bertanya, "Apakah dia punya hutang?", Mereka menjawab, "Ya" maka beliau berkata, "Shalatilah teman kalian ini oleh kalian". Abu Qatadah berkata, "Wahai Rasulullah. Saya yang akan melunasi hutangnya", maka beliau pun mau menyalatinya". (HR. Bukhari)

Jadi, jika seseorang meninggal, di antara hak yang harus ditunaikan sebelum dilakukan pembagian warisan dari harta yang ditinggalkan untuk para ahli warisnya ialah melunasi hutang-hutang si mayit bila ia meninggalkan hutang, baik hutang yang terkait dengan hak Allah maupun hak manusia. Meskipun ketika melunasi hutang-hutangnya tersebut sampai menghabiskan seluruh harta yang ditinggalkannya.

Akan tetapi, jika harta si mayit tersebut tidak mencukupi untuk melunasi hutang-hutangnya, maka apa yang harus dilakukan?

1. Jika hutang-hutangnya berkaitan dengan hak manusia, maka dibolehkan bagi wali mayit untuk meminta pengampunan dari para pemilik harta hutang atas hutang-hutang si mayit kepada mereka, baik sebagian maupun keseluruhan. Hal ini terisyaratkan dalam kisah yang dialami oleh Jabir r.a. ketika ayahnya terbunuh di medan perang Uhud, sementara ia menanggung hutang. Dia meminta kepada para pemilik harta hutang untuk membebaskan sebagian

${ }^{25}$ Ibid., h. 5.

Sangaji Jurnal Pemikiran Syariah dan Hukum 
hutang ayahnya, tetapi mereka menolak dan tetap berkeinginan untuk mengambil hak mereka. Akhirnya Jabir r.a. mendatangi Nabi SAW (dan memintanya menyelesaikan masalah tersebut), maka Nabi meminta kepada mereka agar mau menerima kurma-kurma yang ada di kebun Jabir sebagai pembayarannya dan menghalalkan (membebaskan) sebagian hutang ayahnya, tetapi mereka menolak. Dari kisah di atas terdapat dalil, bahwa wali mayit boleh meminta kepada para pemilik harta hutang untuk membebaskan hutanghutang si mayit. Dan pemilik harta, boleh membebaskan sebagian atau seluruh hutang si mayit.

Dan dari kisah di atas, juga dipahami bahwa bila si mayit tidak memiliki harta yang cukup untuk melunasi hutang-hutangnya, maka dilunasi oleh walinya, atau kerabatnya. Sebagaimana juga disebutkan dalam hadits yang dituturkan Sa'ad bin Athwal r.a., ketika Nabi SAW mengatakan kepadanya. "Sesungguhnya saudaramu tertahan (ruhnya) karena hutangnya, maka lunasilah hutangnya". Kemudian Sa'ad berkata, "Wahai Rasulullah. Aku telah melunasi semuanya, kecuali dua dinar yang diakui oleh seorang wanita, sementara dia tidak punya bukti". Maka Nabi SAW berkata, "Berilah dia, karena dia berhak".

Namun, jika tidak ada seorang pun dari keluarga atau kerabat mayit yang bisa melunasi hutang-hutangnya, maka negara atau pemerintah yang menanggung pelunasan hutangnya, diambilkan dari Baitul Mal.

Dikatakan oleh Nabi SAW, sebagai pemimpin kaum muslimin. "Aku lebih berhak menolong kaum mukminin dari diri mereka sendiri. Jika ada seseorang dari kaum mukminin yang meninggal, dan meninggalkan hutang maka aku yang akan melunasinya..."

Maksud NabiSAW ialah, akan melunasinya dari harta Baitul Mal, yang terdiri dari ghanimah (harta rampasan perang), jizyah (dari orang kafir yang berada dalam naungan kaum Muslimin), infak atau shadaqah serta zakat. Sebagaimana yang dipahami dari pekataan Nabi kepada Jabir (di saat ia tidak mampu melunasi hutang-hutang ayahnya yang wafat dalam keadaan meninggalkan hutang): "Kalaulah telah datang harta (jizyah) dari Bahrain, niscaya aku memberimu sekian dan sekian"

Dan jika negara atau pemerintah tidak menanggungnya, kemudian ada diantara kaum Muslimin yang siap menanggungnya, maka hal itu 
dibolehkan sebagaimana kandungan hadits Salamah bin Al-Akwa ra di atas. Hal itu memberi pelajaran bahwa mayit dapat memperoleh dengan dilunasinya hutang-hutangnya, meskipun oleh selain anaknya. Dengan demikian berarti akan membebaskannya dari azab. ${ }^{26}$

2. Jika hutang si mayit berkaitan dengan hak Allah seperti nadzar haji, maka wajib ditunaikan oleh si mayit dengan harta si mayit bila mencukupi. Sedangkan bila harta si mayit tidak mencukupi ketika wafatnya, maka ditanggung oleh walinya yang akan menghajikan untuk si mayit, sebagaimana kandungan dari hadits Ibnu Abbas r.a., bahwa pernah ada seorang wanita dari Bani Juhainah datang kepada Nabi SAW dan berkata : "Sesungguhnya ibuku telah bernadzar haji, tetapi belum berhaji sampai meninggalnya, apakah aku harus menghajikan untuknya?" Nabi SAW menjawab, "Ya, hajikanlah untuknya. Bukankah jika ibumu menanggung hutang maka kamu yang akan melunasinya? Tunaikanlah hak Allah, karena hak Allah lebih utama untuk ditunaikan"

3. Jika ia memiliki hutang yang berkaitan dengan hak Allah dan hak manusia, manakah yang lebih dahulu ditunaikan?

Dalam permasalahan ini, para ulama berbeda pendapat dalam tiga kelompok, yaitu: Pertama: Harta si mayit yang ada dibagikan untuk hutang-hutang tersebut dengan masing-masing mendapat jatah bagian berdasarkan nisbah (presentase), seperti pada kejadian seorang yang mengalami kebangkrutan, pailit (muflis), yaitu ketika dia menanggung hutang-hutang yang melampaui harta miliknya. Ini adalah pendapat ulama madzhab Hambali.

Kedua: Diutamakan hutang-hutang yang berkait dengan hak manusia, dengan mempertimbangkan oleh sifat asal manusia yang bakhil (tidak memaafkan). Adapun hak Allah dibangun atas dasar sifat Allah yang suka memaafkan. Ini adalah pendapat ulama madzhab Hanafi dan Maliki.

Ketiga: Menurut mazhab Syafi'i yang benar adalah diutamakan hak Allah dari pada hak manusia, berdasarkan keumuman hadits Ibnu Abbas ra di atas, yaitu ketika Nabi SAW bersabda. h. 6 .

${ }^{26}$ Abu Humaid Arif Syarifuddin, Al-Manhaj (Surakarta: Yayasan Lajnah Istiqamah, 2005),

Sangaji Jurnal Pemikiran Syariah dan Hukum 


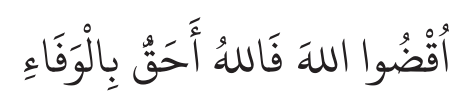

Terjemahan:

Tunaikan hak Allah, karena hak Allah lebih utama untuk ditunaikan (HR. Bukhari). ${ }^{27}$

\section{Kesimpulan}

Wasiat adalah pemberian seseorang pewaris kepada orang lain selain ahli waris baik materi maupun non materi, yang berlaku setelah pewaris meninggal dunia. Sedangkan wasiat wajibah merupakan kebijakan penguasa yang bersifat memaksa untuk memberikan wasiat kepada orang tertentu, pada waktu tertentu. Wasiat wajibah adalah suatu wasiat yang diperuntukkan kepada ahli waris kepada ahli waris atau kerabat yang tidak memperoleh bagian harta warisan, karena adanya halangan syara'. Pada dasarnya persoalan wasiat wajibah mengalami perdebatan baik itu ulama salaf dan khalaf, yang mana dalam konsepnya diberikan kepada anak angkat yang memang tidak mendapatkan pusaka, begitupun cucu laki-laki maupun cucu perempuan yang orang tuannya mati mendahului atau bersama-sama atau bersama-sama kakek atau neneknya (pewasiat).

Ijma kaum muslimin sepakat bahwa tindakan wasiat merupakan syariat Allah dan Rasul-Nya. Ijma' didasarkan pada ayat-ayat Al-Qur'an dan Hadits. Terkait hukum wasiat Helmi Karim mengatakan hukum melakukan wasiat bervariasi, ada yang wajib, sunnah, makruh bahkan ada yang haram, sesuai dengan situasi dan kondisi. Salah satu syarat wasiat adalah apabila yang diwasiatkan harta, jumlahnya tidak melebihi sepertiga. Selain itu mengenai hutang piutang yang mana pengertian yang dipahami adalah memberikan sesuatu yang menjadi hak milik pemberi pinjaman kepada peminjam dengan pengembalian di kemudian hari sesuai perjanjian dengan jumlah yang sama. Hukum hutang piutang sendiri bersifat fleksibel tergantung situasi kondisi dan toleransi. Terlebih hutang itu adalah beban bagi si mayit yang harus ditunaikan sebelum dilakukan pembagian warisan pada harta yang ditinggalkan tersebut. Selain itu, konsekwensi yang didapatkan ketika hutang tersebut tidak

${ }^{27}$ Ibid, h. 7-8.

Vol. 1, Nomor 2, Oktober 2017 
dapat dilunasi itu beragam. Maka perlu untuk selalu diperhatikan mengingat hutang tersebut dapat mengganggu dalam proses baik itu ketika disholatkan dan juga menjadi tanggungan yang harus dilunasi oleh Ahli Waris nantinya.

\section{Daftar Pustaka}

Ad-Dimasyqi, Syaikh al-Allamah Muhammad bin Abdurrahman. Figh Empat Mazhab. Cet. II; Bandung: Hasyimi, 2004.

Elimartati. Hukum Perdata Islam di Indonesia. Batusangkar: STAIN Batusangkar Press, 2010.

Gaffar, Abdul. Hibah dalam Perspektif Hadis Nabi. Cet. 1; Makassar: Alauddin University Press, 2013.

Hasan, M. Ali. Hukum Waris Dalam Islam. Cet. VI; Jakarta: PT. Bulan Bintang, 1996.

Karim, Helmi. Fiqh Muamalah. Cet. III; Jakarta: PT. Raja Grafindo Persada, 2002.

Pasaribu, Chairuman. Hukum Perjanjian Dalam Islam. Jakarta: Sinar Grafika, 1994.

Rahman, Fathur. Ilmu Waris. Jakarta: PT. Bulan Bintang, 1979.

RI, Departemen Pendidikan. Kamus Bahasa Indonesi. Jakarta: Pusat Bahasa Departemen Pendidikan Nasional, 2008.

Saebani. Hukum Perdata Islam di Indonesia. Bandung: CV. Pustaka Setia, 2011.

Sudarsono. Sepuluh Aspek Agama Islam. (Jakarta: PT. Rineka Cipta, 1994. Shomad, Abdul. Hukum Islam Penormaan Prinsip Syariah dalam Hukum Indonesia. Jakarta: Kencana Prenada Media Group, 2010.

Suparman. Fiqh Mawaris (Hukum Kewarisan Islam). Jakarta: Gaya Media Pratama, 1997.

Suparman, Eman. Hukum Waris Indonesia. Bandung: PT. Rineka Aditama, 2005.

Syarifuddin, Abu Humaid Arif. Al-Manhaj. Surakarta: Yayasan Lajnah Istiqamah, 2005.

Sangaji Jurnal Pemikiran Syariah dan Hukum 